\title{
Chapter 8 \\ Diaspora Policies, Consular Services and Social Protection for Danish Citizens Abroad
}

\author{
Romana Careja
}

\subsection{Introduction}

Approximately 250,000 Danish expats are currently living outside the borders of Kingdom of Denmark, mostly in other European Union (EU) countries and the United States of America (USA). This chapter explores the question of how the Danish Government is relating to this group of its citizens by focusing on whether and which diaspora-targeted policies exist, which social rights can be retained while residing abroad, and whether and how state institutions have attributes in supporting Danish citizens residing abroad.

Based on evidence from legal and administrative documents, as well as on communications with key informants, and on the review of existing studies and reports, two main observations concerning the way in which the Danish Government interacts with the Danish diaspora can be formulated right from the beginning. Firstly, there has been limited effort to create/promote policies that directly target the Danish diaspora. With very few exceptions, the Danish Governments' approach to Danish diaspora, especially in the area of welfare, has been through the general legislation designed primarily for residents. As a general rule, the embassies and consulates have no attributes in what concerns the provision of, or facilitation of provision of welfare to Danish citizens residing abroad. If, on a case-by-case basis, it is decided that consular service (in the form of direct help or advice) may be provided, it comes with a financial cost. Secondly, Danish citizens lose access to most of the social benefits to which they are entitled in Denmark once they move their residence abroad.

Several factors may explain the limited development of diaspora policies in Denmark and the limited access to Danish welfare benefits by Danish citizens

\footnotetext{
R. Careja $(\bowtie)$

University of Southern Denmark, Odense, Denmark

e-mail: rca@sam.sdu.dk
} 
residing abroad. Firstly, the coverage of the universal Danish welfare state is extended to individuals based on residence and not on citizenship. Therefore, as soon as a person officially does not reside in Denmark, he or she loses many of the social rights to which he/she would be otherwise entitled as resident, even if that person is a Danish citizen. Secondly, I suggest that the existence of the EU legal framework on cross-border welfare, and the strong cooperation among Nordic countries via social security agreements to support the mobility of Nordic citizens in Nordic area likely reduce the incentive for Danish authorities to develop ad-hoc policies for its diaspora. Thirdly, the relative neglect of diaspora-related issues may reflect the small size of the Danish diaspora, and, arguably, the constructed image of emigrants as ungrateful and selfish individuals (Mouritsen and Jensen 2017) may have additionally discouraged authorities to take an open interest in the diaspora.

The chapter is structured as follows: the first section presents contextual information concerning Danish consular service provision and diaspora policies. Then, the chapter traces different welfare entitlements accessible to Danish citizens abroad (with a particular focus on Danes living in Sweden, Norway, Germany, the United Kingdom (UK) and the USA, which are the primary destination countries for Danish citizens abroad) and the role of Danish authorities in accessing these rights.

\subsection{Diaspora Policy Infrastructure and Key Policies}

\subsubsection{The Danish Diaspora and Its Relations with Homeland}

Historically, Denmark has been a country of emigration: between 1850 and 1950, poverty had pushed an estimated 400,000 Danes to seek their fortunes on other shores. Most emigrated to the USA, but also to Canada and Argentina (Mouritsen and Jensen 2017; Grøngaard Jeppesen 2005). Currently, an estimated 250,000 Danish citizens (including children) are residing outside the Danish borders. ${ }^{1}$ The countries hosting the largest Danish diaspora are Sweden, Norway, Germany, the USA and the UK. Table 8.1 below illustrates the emigration flows to these countries over the last 5 years, compared to the Danish citizens emigrating to all other European Economic Area (EEA) countries, plus Canada, Australia and New Zealand, estimated based on the numbers of Danish citizens who inform Danish authorities that they move to these countries.

Contrary to the centrality of immigration, emigration is not a major topic, neither for Danish politicians, nor for the Danish public. This is not to say that is completely out of the limelight. For most of the last two decades, Danish emigration has been mostly depicted in negative terms, as a brain drain, while emigrants were often portrayed as selfish individuals who chose personal benefits over staying in Denmark

\footnotetext{
${ }^{1}$ Estimate provided in the 2016 report The Danish Diaspora - An Untapped Resource? by Copenhagen Goodwill Ambassadors \& Danes Worldwide.
} 
Table 8.1 Yearly outflow of Danish citizens

\begin{tabular}{l|l|l|l|l|l}
\hline & 2014 & 2015 & 2016 & 2017 & 2018 \\
\hline Sweden & 1822 & 1842 & 1989 & 1736 & 1811 \\
\hline Norway & 1599 & 1360 & 1241 & 1158 & 1228 \\
\hline Germany & 1616 & 1571 & 1614 & 1488 & 1531 \\
\hline USA & 2034 & 2400 & 2211 & 1937 & 1796 \\
\hline United Kingdom & 2354 & 2393 & 2140 & 2023 & 1776 \\
\hline All other EU/EEA, CAN, NZ, AU & 4805 & 4803 & 5073 & 5475 & 5572 \\
\hline
\end{tabular}

Source: Statistics Denmark (2019), Table VAN2KVT (www.dst.dk

and contributing to the welfare state that supported them. ${ }^{2}$ Some politicians even argued that, in order to discourage graduates of Danish universities to move and work abroad, the Government could turn the generous education grants into zerointerest loans that would need to be repaid in case a graduate would opt for career abroad (Mouritsen and Jensen 2017). The tone has become more positive in recent years as data has shown that most Danes (between 70 and $80 \%$ ) tend to return after about 10 years spent abroad (Mouritsen and Jensen 2017; Redington 2003). Some scholars have suggested that that the relatively low number of Danes living abroad, as well as their tendency to return after relatively short periods partly account for fact that diaspora-related issues and emigration policies score rather low on the political agenda (see for example, Mouritsen and Jensen 2017).

This apparent lack of interest on the part of the Danish state is not without consequences. In 2016, Copenhagen Goodwill Ambassadors \& Danes Worldwide (CGA\&DW) conducted a survey ${ }^{3}$ among their members with the aim of identifying how the Danish citizens living abroad experience the connection with the home country. According to this survey, the main reasons for which Danes move abroad are career opportunities and personal relationships (see also Madsen 2009). The survey also found that, while Danes are keen to maintain a connection with Denmark, they also are critical of the limited way in which Danish authorities connect with the diaspora. Moreover, specific barriers such as loss of voting rights (as early as 2 years after leaving Denmark), ${ }^{4}$ stringent requirements for family reunification, difficulties in accessing or maintaining citizenship (until 2015, Denmark did not accept dual

\footnotetext{
${ }^{2}$ Mouritsen and Jensen (2017:55) quote a Danish Liberal Party MP saying "if you really are concerned about Denmark and have feelings for your country, you might come home from your tax shelters and contribute to it" (quote retrieved from Brogaard Pedersen 2009).

${ }^{3}$ The survey is not based on a representative sample of Danes living abroad. The survey has been sent by email the members of Copenhagen Goodwill Ambassadors and was posted on social media sites aimed at Danish citizens living abroad. 960 responses were received via the Danes Worldwide network, and 64 Copenhagen Goodwill Ambassadors answered (79\%) (CGA\&DW 2016:5).

${ }^{4}$ Voting rights are lost if a person resides abroad longer than 2 years, with exception of specific groups, for example government employees working in Danish representations abroad. Those intending to vote must request to be included in the electoral register of the municipality of origin (assimilated representation). Voters who are staying abroad may cast their vote in advance with a Danish diplomatic or consular mission or with a 'vote receiver' appointed by the Minister for Economic Affairs and the Interior, cf. sect. 57 of the Folketing Election Act. A 'vote receiver' is a
} 
citizenship) and the lack of political influence contribute to Danish diaspora's overwhelming perception that it is not a priority for the Danish state (CGA\&DW 2016). Danish authorities have recently indicated that their position on diaspora issues is changing. A sign in this direction has been the creation in 2018 of a task force with the aim of providing the Government with advice on how to engage the Danish diaspora. ${ }^{5}$ For example, although the diaspora is still not officially represented in any homeland governmental body, organisations that represent diaspora, such as Danes Worldwide (danes.dk) have recently been involved in ad-hoc consultations or information sessions with homeland authorities.

\subsubsection{Diaspora Infrastructure}

Denmark does not have any official governmental agencies or institutions that deal with Danish citizens residing abroad and efforts to organize or engage with the diaspora are extremely limited (see below, Sect. 8.2.3). ${ }^{6}$ According to Mouritsen and Jensen, "[diaspora engagement policies] are really non-existent in the Danish case, and there is very little of [diaspora-building policies]" (2017:56). Consequently, Denmark does not have diaspora infrastructure per se, as a set of institutions financed and managed by the Danish state that are explicitly designated to look after the Danish citizens residing abroad. In absence of such institutions, one can however identify other institutions which provide some degree of support to the Danish diaspora.

Firstly, Denmark has a well-developed network of representations abroad, which includes embassies, general consulates and a large network of around 400 honorary consulates. In the five countries of interest in this chapter, Denmark has the following representations in addition to embassies: in Sweden: one general consulate and 15 honorary consulates; in Norway: one general consulate and 13 honorary consulates; in Germany: three general consulates and 11 honorary consulates; in Great Britain: one general consulate and 20 honorary consulates; and in the USA:, four general consulates and 38 honorary consulates. ${ }^{7}$ While the embassies and general consulates are responsible with implementing Danish foreign policy, representing Denmark abroad and protecting and assisting the Danish nationals abroad, the honorary consulates' main aim is to provide support in the name of the Danish state for example in critical situations - deaths, accidents, assaults, etc., when other help is

person who is legally allowed to receive/collect the votes of Danish citizens abroad who have the right to vote.

${ }^{5}$ Communication with a representative of Danes Worldwide. Accessed 4 February 2019.

${ }^{6}$ Email communications with a representative of Danes Worldwide. Accessed 24 August 2018. Additionally, no information about diaspora-related policies and institutions on the website of the Ministry of Foreign Affairs exists.

${ }^{7}$ Ministry of Foreign Affairs website, http://um.dk/da/om-os/organisation/. Accessed 24 August 2018. 
not available. Most of the support that these institutions offer are for travellers (see Sect. 8.2.3 below), although some services may be offered to Danish citizens residing abroad as well.

Secondly, the Danish state provides financial support to the Danish ethnic minority living in the North of Germany. This policy is similar to what has been observed in the case of other EU Member States. The funds are used to support a Danishlanguage newspaper and several other cultural initiatives aimed at maintaining ties with the Danish culture. However, it needs to be mentioned that the Danish ethnic minority (counting ca. 50,000 individuals), which is composed of German citizens with strong Danish affinities, is not considered "Danish diaspora" (Mouritsen and Jensen 2017). The Danish ethnic minority in the North of Germany has resulted from political and historical events taking place at the end of 19th and beginning of the twentieth century. The Copenhagen-Bonn declarations in 1955 have established the basis for cooperation between Denmark and Germany with regard to their respective minorities living on each other's territories. ${ }^{8}$

Thirdly, NGOs, the National Church, and emigrant associations active in destination countries play an important role in supporting Danish diaspora. These organisations coalesce Danes abroad and provide a network of support and, to some extent, connection to homeland. One such organisation is the National Church (Folkekirken). Given Denmark's history as a maritime power, there is a widespread network of Danish churches in the main seaports of the world. In addition to religious services, the Danish Churches organize cultural and social events, and offer Danish language courses (Mouritsen and Jensen 2017, see also folkekirken.dk). As the Church is largely state financed, one could argue that the Danish state is indirectly providing support for the Danes abroad via this channel.

Another non-state organisation is Danes Worldwide (danes.dk), which, with headquarters in Copenhagen and a network of regional representatives around the globe, is a wide-reaching organization. The organization provides overall counselling, and networking opportunities for Danes worldwide. They also organize Danish language programs for adults and children, and a summer school - thereby supporting the desire of Danish citizens abroad to maintain the ties with the home country, its language and culture. ${ }^{9}$ Danes Worldwide has received financial support from the Ministry of Education for the Danish language classes (Mouritsen and Jensen 2017). However, Danes Worldwide does not receive public funds on a regular basis, and it competes with other organisations for governmental grants. But instances when grants are offered are rare.

The embassies/consulates do cooperate with organizations representing Danish citizens abroad, although it is mostly ad-hoc. For example, Danes Worldwide notes that they cooperate with embassies/consulates in cases such as assistance for transportation of bodies of dead relatives or legal counselling in paternity cases. Other

\footnotetext{
${ }^{8}$ For details, see The Danish ethnic minority, http://tyskland.um.dk/da/om-tyskland/danske-mindretal-i-sydslesvig/den-dansk-tyske-mindretalsordning/. Accessed 24 August 2018.

${ }^{9}$ Communication with a representative of Danes Worldwide. Accessed 24 August 2018.
} 
forms of cooperation include exchange of local knowledge regarding understanding of local regulations on citizenship etc. In certain cases, the Ministry links to Danes Worldwide as contacts for local representation etc. ${ }^{10}$

While Danes Worldwide is a general organization, others are more issue-specific. For example, Agteskab Uden Granser concentrate their efforts on problems regarding family reunification with foreign spouses, while Danes Abroad Business Group Online (DABGO) or the Chambers of Commerce tend to look towards businesses. During research for this study, it was unclear to what extent these, and other similar organisations, benefit from regular support from the Danish state, as the Ministry of Foreign Affairs does not communicate public information on cooperation and financial support for organisations of Danish citizens living abroad. Based on the example of Danes Worldwide, it is reasonable to assume that at least some of them receive project-based grants from the ministries closest to their activities.

As a strong volunteer sector is part of the Danish ethos, it is likely that in each of the five major destination countries (Sweden, Norway, Germany, the UK and the USA) there are organizations that cater to various needs of Danish citizens abroad. However, little centralized information about these organizations exists. Among the five countries, only the embassies in the $\mathrm{UK}^{11}$ and Sweden ${ }^{12}$ provide a list of such organizations on their websites. There is also evidence that Danes abroad organize themselves and finance some activities. For example, established online platforms such as Facebook or the Internations network are often used for information exchange about rights and opportunities in the host countries, while Danish schools, such as the Scandinavian School in Berlin, the Danish school in London and the one in Washington, are financed and run privately (Mouritsen and Jensen 2017).

\subsubsection{Key Engagement Policies}

Denmark provides general consular assistance to Danish citizens abroad under the Foreign Service Act (Lov om Uderingstjenesten, Law 150 of 13.04.1983 amended by law 331 of $14.05 .1997, \S 1$ in law nr. 410 of 6.06 .2002 , law nr. 753 of 2.06.2015 and law 316 of 25/04/2018), complemented by internal regulations, such as the Instructions on Consular Affairs (Borgerserviceinstruktsen, not publicly available) and the executive orders which detail paid services provided by the Danish foreign services. Consequently, consular assistance is provided under the law and not as a matter of policy (CARE 2010:146).

No separate national consular law exists. The section 1(3) of Law 150 of 13.04.1983 (amended by Law 410 of 6.06.2002) stipulates that the Danish Foreign

\footnotetext{
${ }^{10}$ Communication with a representative of Danes Worldwide. Accessed 24 August 2018.

${ }^{11}$ For details, see http://storbritannien.um.dk/en/About\%20Great\%20Britain/danish-organisations-and-institutions-in-the-uk/. Accessed 24 August 2018.

${ }^{12}$ For details, see http://sverige.um.dk/da/om-sverige/danske-foreninger-og-menigheder-i-sverige/. Accessed 24 August 2018.
} 
Service assists Danish citizens and Danish enterprises in their commercial relations with foreign countries. This provision is interpreted to include a right to consular assistance. The Instructions on Consular Affairs have the force of administrative circulars and describe how assistance is to be provided. Complaints about inadequate assistance are handled by the Ministry of Foreign Affairs, but can be lodged also through the legal system (CARE 2010:146).

The above-cited CARE report on consular services notes that, according to the Ministry of Foreign Affairs, "providing consular assistance to Danes abroad is one of the highest priorities, and that Denmark offers extensive consular services to its citizens" (CARE 2010: 147). The Ministry's Annual Reports ${ }^{13}$ indeed indicate that financial resources are used for assistance, but do not contain details as to the cases and types of consular support/assistance provided. A look at the website of the Ministry of Foreign Affairs and a reading of the Foreign Service Act (see below) suggest that this assistance is predominantly targeted to Danish citizens travelling abroad and/or finding themselves in special/urgent situations, and less so towards Danish citizens residing abroad, while some information provided targets Danes planning to move abroad.

The Ministry of Foreign Affairs' Citizens' Service (Borgerservice) ${ }^{14}$ provides, through the Danish Embassies and Consulates, services/help in the following situations:

- Advice about transfer of money for return-trip

- Issuance of temporary passports

- Contact a lawyer, in case of arrest

- Contact with relatives in Denmark

- Contact to an insurance company in case of illness, accident or death

- Information on risk areas

In addition, the consulates provide other services as established by the orders VEJ 10215 of 14.12.2017 and BEK 1467 of 11.12.2017. All services are fee-based. Individuals can expect to pay DKK 1.010 (ca. 136 EUR) for each commenced hour for most services that involve some form of personal assistance, Issuance of documents is also, unless otherwise stated, priced at DKK 1.010 (ca. 136 EUR) per document. The consulates offer the following services: visas, processing of work and residence documents for nationals of other countries who will reside and work in Denmark, issuance of copies of driver license for a variety of situations, legalizations and control of Danish citizens' identity, proof of Danish citizenship of children born abroad of Danish parents, and a variety of commercial/trade-related services, such as authentication of documents, various forms of assistance (drafting letters, procurement of certificates, transfer of documents, etc.). Most of these

\footnotetext{
${ }^{13}$ For details, see http://um.dk/da/om-os/organisation/oko/okonomi/ Accessed 15 March 2020.

${ }^{14}$ For details, see http://um.dk/da/rejse-og-ophold/udenrigsministeriets-borgerservice/hvad-kanudenrigsministeriets-borgerservice. Accessed 15 March 2020.
} 
services are priced between 130 and 195 EUR per document, with lower amounts for driver licences. ${ }^{15}$

The Foreign Ministry's Citizens' Service (Borgerservice) explicitly states on the Ministry's website ${ }^{16}$ that Danish Embassies and consulates do not:

- Lend money or make bank transactions ${ }^{17}$

- Pay out assistance or pension

- Get a person released from prison or pay for lawyer

- Pay a hospital or doctor

- Get a job or work permit

Each embassy has on its own website general information about the services mentioned above, as well as country-specific information. According to Danes Worldwide, it is possible that embassies/consulates may decide to provide some assistance with contacting the institutions delivering social services, but this is more the exception than the rule, and is done on case-by-case basis. ${ }^{18}$

\subsection{Diaspora Policies and Social Protection in Denmark}

Access to social rights for members of Danish diaspora is directly influenced by the nature and organisation of the Danish welfare state. On the one hand, Denmark has a universal welfare system, where any legal resident of Denmark has the right to access all benefits and services - given fulfilment of conditions for specific benefits. The connection between legal residents and the administrative system managing the whole array of services and benefits is mediated via the portal Borger.dk, where individuals not only get detailed information about benefits and services (conditions, rules, laws), but also can directly access the relevant administrative units managing these service/benefits and present their cases/requests. The latter can be done securely online, based on personalized login credentials given to each legal resident. On the other land, by law, any resident of Denmark intending to move abroad for a period of time longer than 6 months, must de-register himself/herself from the

\footnotetext{
${ }^{15}$ Udenrigsministeriet (2017). BEK $\mathrm{nr} 1467$ af 11/12/2017. Bekendtgфrelse om betaling for tjenestehandlinger $i$ udenrigstjenesten (https://www.retsinformation.dk/Forms/R0710. aspx?id=195130); Udenrigsministeriet (2017). VEJ nr 10215 af 14/12/2017. Vejledning til bekendtgфrelse om betaling for tjenestehandlinger iudenrigstjenesten (https://www.retsinformation.dk/ Forms/R0710.aspx?id=195140). For updated list of prices and services, see http://um.dk/en/traveland-residence/payment-for-services/. Accessed 24 August 2018.

${ }^{16}$ For details, see http://um.dk/da/rejse-og-ophold/udenrigsministeriets-borgerservice/hvad-kanudenrigsministeriets-borgerservice. Accessed 15 March 2020.

${ }^{17}$ In special situations, the consulates can decide to provide financial advances. However, as a matter of principle, this is conditional upon a written guarantee or transfer of money to the embassy/ consulate in question (CARE 2010, p150).

${ }^{18}$ Communication with a representative of Danes Worldwide. Accessed 24 August 2018.
} 
Central Population Register. ${ }^{19}$ As a great deal of social rights are residence-based, it means that as soon as they move abroad for more than 6 months, Danish citizens are losing access to social/welfare benefits. However, some welfare entitlements can be transferred across borders, provided that certain conditions are fulfilled, as the following sub-sections illustrate.

The Danish Government does not have an information dissemination strategy specifically targeting its nationals abroad concerning social protection issues. However, public information concerning the social rights is widely available. In full details, it can be retrieved on the portal Borger.dk. The website of the Ministry of Foreign Affairs and the websites of some embassies contain basic information about social rights of Danish nationals residing abroad (or who intend to move abroad) and possibly links to Danish and host countries' laws and institutions (for examples, see the presentation of the social rights in the following subsections). From 2007, the Ministry of Foreign Affairs opened a 24/7 citizens support center line, which provides telephone assistance. In addition, the Tax Office (SKAT) provides information concerning tax liability and the bilateral agreements on double taxation, both issues of relevance for citizens abroad.

Denmark does not have an explicit repatriation policy. However, in case of death abroad, a Danish embassy or a Danish consulate helps with ensuring that Danish police promptly inform closest relatives in Denmark. The embassy or consulate can advise and assist in the cremation and/or home transport of the urn or coffin - or with local funeral. However, they do not pay for these services. ${ }^{20}$ Transportation of a body across border necessitates a special passport (ligpas). This can be provided upon presentation of the following documents: 1) death certificate issued by a doctor; 2) registration of death with authorities; 3) document from funeral firm stating the conditions for body transportation; 4) soldering documentation for zinc coffins; 5) embalming documentation. The passport is not needed for urns. The relevant laws concerning repatriation of bodies are Circular 15,480 from 26.09.1983 and Announcement 152 from 14.04.1983. ${ }^{21}$

As a rule, Danish embassies and consulates do not provide in-cash or in-kind contributions to nationals abroad. In exceptional cases only, consulates can decide to provide 'financial advances'. However, as a matter of principle, this is always conditional upon a written guarantee (commitment to reimburse), or a transfer of money to the embassy/consulate in question (CARE 2010:150).

\footnotetext{
${ }^{19}$ De-registration is done by directly contacting the Central Population Register (CPR) and officially announcing the intention of residing abroad for more than 6 months. This process is voluntary and no penalties are envisaged for failure to do so. See for details https://www.dst.dk/en/ Statistik/dokumentation/documentationofstatistics/migration-to-and-from-denmark/accessibilityand-clarity. Accessed 15 March 2020.

${ }^{20}$ For details, see http://um.dk/da/rejse-og-ophold/hvis-uheldet-er-ude/doedsfald/. Accessed 15 March 2020.

${ }^{21}$ For details, see https://stps.dk/da/sundhedsprofessionelle-og-myndigheder/ligsyn-og-obduktion/ udstedelse-af-ligpas. Accessed 15 March 2020.
} 
In spite of limited engagement of consular authorities in the area of social protection as a matter of practice, the Danish case is noteworthy for commitment to tight regional cooperation within Nordic region, via the Nordic Convention on Social Assistance and Social Services. ${ }^{22}$ The Convention, signed by Denmark, Norway, Sweden, Iceland and Finland, was justified as an addition to the right to social benefits arising from the Agreement on the European Economic Area of 2 May 1992 because "there is still a need for special Nordic rules on social assistance and social services" (quote from the second paragraph of the Preamble). The Convention is periodically renewed/revised/updated, and executive orders are issued for its implementation. As a result of a recent update, the Executive Order of the Nordic Convention of 12 June 2012 on social security and associated administrative agreement was adopted in 2014 (BKI 12 of 18.08.2014 ${ }^{23}$ ) and is currently in force. The Convention complements other agreements between the Nordic states which aim at facilitating mobility of individuals across borders (for example, the 1996 Agreement of mutual access to higher education, ${ }^{24}$ or a Multilateral Agreement on Labour Migration which grants unrestricted access to all Nordic Countries' citizens to the labour markets of the Nordic countries), which all originate in the 1962 Helsinki Treaty - a cooperation treaty between Denmark, Finland, Iceland, Norway and Sweden. ${ }^{25}$ The Convention does not provide Nordic countries' citizens with new/ extra rights in the area of social protection, but makes the transfer of welfare entitlements across their borders easier and sets the basis for advanced institutional cooperation in this area among Nordic countries. The existence of these agreements smoothens the administrative burdens for mobility within the Nordic region and may be an additional reason for which additional policies that address diasporarelated issues have not been developed by the Danish Government alone.

Important from the perspective of this chapter, the Nordic Convention, its updates and the subsequent executive orders specify that the administration of welfare entitlements is to be conducted by the public authorities responsible for the delivery of the respective services in the countries of residence or/and home countries, depending on the personal situation of the citizens. The public authorities (listed in the Annex 4 of the Convention) are to set cross-country liaison units for a smooth delivery of services (see Article 12 of the Nordic Convention, and Article 10 of the

\footnotetext{
${ }^{22}$ See Bekendtgørelse af Nordisk Konvention af 14. juni 1994 om Social Bistand og Social Tjenester (online at https://www.retsinformation.dk/forms/r0710.aspx?id=83047); recent version (BKI 12 of 18.08.2014) available online at https://www.retsinformation.dk/forms/R0710.aspx?id=164155. Accessed 24 August 2018.

${ }^{23}$ Udenrigsministeriet (2014). BKI nr 12 af 18/08/2014. Bekendtg $\phi r e l s e$ af nordisk konvention af 12. juni 2012 om social sikring med tilhørende administrativ aftale (online at https://www.retsinformation.dk/forms/R0710.aspx?id=164155). Accessed 24 August 2018.

${ }^{24}$ For details, see https://www.norden.org/en/declaration/agreement-concluded-denmark-finlandiceland-norway-and-sweden-admission-higher. Accessed 15 March 2020.

${ }^{25}$ For details, see https://www.norden.org/en/publication/helsinki-treaty-0. Accessed 15 March 2020.
} 
Administrative Agreement to the Nordic Convention on Social Security). ${ }^{26}$ The implication of these provisions is that other institutions, in particular the representations of Denmark in other Nordic countries, are not involved in the administration and delivery of any social services.

In the following sub-sections, the main Danish social protection policies that concern Danish citizens abroad will be presented. For each policy area, the content of policies/services, as well as eligibility conditions for nationals living abroad (if applicable) are introduced. This overview illustrates that the Danes living abroad qualify for only a fraction of the benefits and services provided by the Danish welfare state. Moreover, it also illustrates the limited role of Danish consulates and embassies.

\subsubsection{Unemployment}

To receive unemployment benefits, a person must be a resident in Denmark and must be a contributing member of an unemployment insurance fund (A-kasse) for at least 52 weeks. Special rules apply for graduates, including an exemption from the 52-week contribution period. As a rule, an A-kasse member has a right to unemployment benefits for a maximum of 2 years in total within a three-year period. ${ }^{27}$ To receive the benefits, the person: (1) must be available for work with one day's notice; (2) must have earned/have had an income of at least DKK 228,348 (in 2018) (ca. 30,611 EUR) during the last three years (in total) for full-time insured, or DKK 152,232 (ca.20,407 EUR) if is part-time insured (Indkomstkravet) ${ }^{28}$; 3) must register as a job seeker with a local job centre; and 4) demonstrably must actively look for jobs and be willing to accept job offers.

As in all EU Member States, EU legislation allows that a person who is wholly unemployed and entitled to receive unemployment benefits in Denmark can transfer its benefits in another Member State for minimum three to maximum six months if the move abroad is with the aim of searching for jobs. The A-kasse webpages provide information on the conditions attached to this transfer, which include proven registration with a job-centre abroad within one week of establishing residence..$^{29}$ If a Danish citizen opts for a short-term transfer of unemployment benefits abroad in the conditions highlighted by relevant legislation, is the person's own responsibility to ensure that the conditions and documentation required is correct and processed on time. The rules apply only if the transfer occurs between two EU countries and

\footnotetext{
${ }^{26}$ Udenrigsministeriet (2014). BKI nr 12 af 18/08/2014. Bekendtg $\phi r e l s e$ af nordisk konvention af 12. juni 2012 om social sikring med tilhørende administrativ aftale (online at https://www.retsinformation.dk/forms/R0710.aspx?id=164155). Accessed 24 August 2018.

${ }^{27}$ For details, see https://www.a-kasser.dk/benefits.html. Accessed 15 March 2020.

${ }^{28}$ For details, see https://www.a-kasser.dk/benefits.html. Accessed 15 March 2020.

${ }^{29}$ For details, see https://a-kasser.dk/transferring-unemployment-benefits.html. Accessed 15 March 2020.
} 
are covered by EU regulations. The Nordic Convention on Social Assistance and Social Services does not provide for any additional benefits in case of unemployment. Unemployment benefits from Denmark cannot be transferred if a person moves to a non-EU country. The Social Security Agreement signed in 2008 between Denmark and US does not concern transferability of unemployment benefits.

Overall, the rules concerning unemployment benefits in Denmark imply that a Danish citizen residing on the territory of another country cannot receive unemployment benefits from Denmark, except for a limited period of time.

As to institutional support, the Danish embassies and consulates do not have any attributes concerning the access and distribution of Danish unemployment benefits, or in helping Danish nationals to access these benefits abroad. Among the five countries of interest, only the Danish embassies in Sweden, Norway and Germany provide information concerning the unemployment rules and institutions to be contacted.

\subsubsection{Health Care}

All legal residents in Denmark are entitled to public healthcare benefits in kind. The legal residence criterion implies that once a person moves his/her residence abroad, he/she is not covered anymore by the public healthcare scheme. Danish citizens abroad are expected to be covered by the healthcare schemes existing in the host countries.

In addition to access to healthcare via de national healthcare system, Danish residents can qualify for sickness benefits (sygedagpenge) if they are unable to work because of illness or because of injuries. A person can receive sickness benefits from the first day of not being able to work. The payment of sickness benefit ends on the day the person returns to work. As a general rule, the recipients of sickness benefits must live in Denmark and pay income tax in Denmark. However, there may be exceptions, as provided in EU legislation, if the recipient of the sickness benefits lives in another EU country or move within the EU or to a country with which Denmark has entered into a separate agreement. ${ }^{30}$ For Danes living in the US, the social security agreement signed in 2008 between Denmark and US does not concern transferability of sickness benefits or other health-related rights.

The law on sickness benefits details the conditions under which sickness benefits can be paid abroad: if the stay abroad has been recommended by medical doctor; if it was approved by the National Health Board; if the person works abroad for maximum one year for an employer in Denmark; if the person is covered by EC Regulation No $1408 / 71$ or if the person is covered by Danish social security

\footnotetext{
${ }^{30}$ For details, see https://www.borger.dk/arbejde-dagpenge-ferie/Dagpenge-kontanthjaelp-ogsygedagpenge/Sygedagpenge/sygedagpenge-hvis-du-er-ledig; see also Beskæftigelsesministeriet (2018). LBK nr 809 af 20/06/2018 Bekendtg $\phi$ relse af lov om sygedagpenge (online at https://www. retsinformation.dk/Forms/R0710.aspx?id=202058). Accessed 24 August 2018.
} 
legislation under an international social security agreement (see $\S 3$, para 2 and $\S 18$ of the Law 809 of $20.06 .2018^{31}$ ). The sickness benefits are disbursed by municipalities, which have (according to $\S 18$ of the law 809 of 20.06.2018) the possibility of convening the recipient of sickness benefits (even if he/she resides abroad, at municipality's cost) for case evaluation. As a general rule, a person can receive sickness benefits for a maximum of 22 weeks within a nine-month period. Before the 22 weeks have elapsed, the municipality will reassess the case to determine whether conditions are met for an extension the sickness benefit period. The conditions are detailed on the Borger.dk portal. ${ }^{32}$

In the area of health, Danes who move to another Nordic country enjoy a certain degree of support. Article 7 of the Nordic Convention refers to the situation when a person residing in a Nordic country and entitled to benefits in kind there temporarily receives a treatment in another Nordic country. In this case, the country of stay (the latter) shall cover the additional expenses incurred on returning to the country of residence. This provision does not apply to persons who are allowed to travel to another Nordic country for the necessary treatment. Similarly, Article 6 of the Administrative Agreement clarifies the administrative procedures and the fact that a decision on reimbursement shall be taken by the relevant institution in the place of residence before returning. ${ }^{33}$

Given the existing institutional support for health care, the Danish embassies and consulates do not have any attributes concerning healthcare- and sickness benefitsrelated issues. The embassies in Sweden, the UK, Norway and Germany provide information about healthcare systems in both the host countries and Denmark, while the embassy in the US does not provide this kind of health-related information.

\subsubsection{Pensions}

Danish citizens have the right to receive their Danish pension abroad, but conditions apply depending on the type of pension (old age or early) and the country where a retired person intends to move in order to reside. Detailed explanations are provided online on Borger.dk. ${ }^{34}$ In addition, the possibility of Danish citizens to take/receive Danish pensions (and additional benefits) abroad is regulated by the Nordic Convention on Social Security, which applies for the case in which Danish citizens

\footnotetext{
${ }^{31}$ For details, see LBK nr 809 af 20/06/2018 (online at https://www.retsinformation.dk/Forms/ R0710.aspx?id=202058). Accessed 24 August 2018.

${ }^{32}$ For details, see https://www.borger.dk/arbejde-dagpenge-ferie/Dagpenge-kontanthjaelpogsygedagpenge/Sygedagpenge/Sygedagpenge-hvis-du-er-loenmodtager. $\quad$ Accessed 24 August 2018.

${ }^{33}$ For details, see BKI nr 12 af 18/08/2014 (online at https://www.retsinformation.dk/forms/R0710. aspx?id=164155). Accessed 24 August 2018.

${ }^{34}$ For details, see https://www.borger.dk/pension-og-efterloen/International-pension/Danskpension-i-udlandet/International-pension-flytte. Accessed 24 August 2018.
} 
reside on the territory of another Nordic state. Pursuant the Article 9 of the Nordic Convention, complemented by the Administrative Agreement, whose Article 10 focuses on administrative implementation of the Nordic Convention, if calculations of pension rights involve taking into account residence periods in different Nordic countries - the respective institutions managing pension rights in these countries will exchange the relevant information. In addition to the Nordic Convention, the social security agreement signed in 2008 between Denmark and the US regulates the transferability of pensions between the two countries.

In what concerns the payment of pensions abroad, Udbetaling Danmark (Payment Denmark) is the sole institution in charge. ${ }^{35}$ Udbetaling Danmark must be contacted directly by Danish citizens who intend to move abroad as pensioners, as well as by Danish citizens who become pensioners while residing abroad, as it is the sole institution that evaluates each case and decides whether and how a Danish citizen can receive pension abroad. Once a year, Udbetaling Danmark International Pension asks pensioners abroad to certify they are alive. On May 1st, Udbetaling Danmark send a life certificate to pensioners abroad by post. The deadline for answering is August 31st. This communication takes place directly between pensioners and Udbetaling Denmark. Therefore, as a rule, Danish embassies and consulates do not have attributes in relation to pensions. At most, some provide web-based information to redirect citizens towards institutions that manage pensions, as it is the case with the embassies in Sweden, Norway and Germany. However, upon request and at a cost, Danish consulates may provide the life certificate form and assistance with filling it. ${ }^{36}$

\subsubsection{Family-Related Benefits}

Family benefits are mostly targeted to children via children allowance (børney-

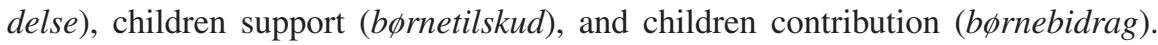
Partner contribution (agtefallebidrag) is paid in case of divorce or separation.

This section focuses on benefits concerning children, as they are the most important family benefit. As a general rule, a child is entitled to any of the benefits if she/ he does not receive other public funds and has not entered into marriage. An earnings principle also applies: under the Law on child allowance and advance payment of child support (LBK 63 of 21.01.2019), the child provider/carer must have been resident or employed in the kingdom for 6 years in the last 10 years in order to qualify for full benefit. Last but not least, there is a residence principle: the child provider/carer must have permanent residence in Denmark and that the child is

\footnotetext{
${ }^{35}$ Udbetaling Danmark is responsible for a number of public services - such as housing support, old-age pension, early retirement, maternity allowance, family benefits, international retirement, international social security, funeral care, retirement benefit, compliance assistance and flexible care.

${ }^{36}$ Communication with Consulate worker. Accessed 22 November 2018.
} 
actually living in Denmark. The implication of these residence criteria is that, as a rule, Danish nationals abroad do not qualify for Danish child benefits, and are expected to obtain child benefits in the countries where they reside, if they qualify for them. ${ }^{37}$

However, three exceptions exist from the residence rule. First, if the main child provider/carer is a retiree who receives a pension while staying abroad, he/she also has the right to receive special child allowance abroad. ${ }^{38}$ Second, children who reside abroad are eligible for benefits in certain conditions: they do not receive any contributions in the country in which they reside; they are on a short-term vacation or they have to go to school abroad. In this latter case, the benefit request must be approved by the municipality in which the child provider/carer claiming benefits resides (see Article 5 of LBK 63 of 21.01.2019). ${ }^{39}$ Third, Danish nationals are entitled to child benefits if, while being posted in another EU country or in similar conditions under EC Regulation 883/04, they are covered by Danish social security legislation even if they reside in another EU country. ${ }^{40}$

The rules on nationality and residence may be waived according to international conventions. For example, children of parents from other Nordic countries and children of persons who, under EC Regulation 883/04 are covered by Danish social security legislation are entitled to child allowances as soon as they reside in Denmark. The same applies when Danish parents reside in other Nordic countries. In addition, Article 11 of the Nordic Convention clarifies the procedures through which the authorities in change of distributing family-related benefits in the Nordic countries where Danish citizens reside must communicate with Danish authorities when they calculate these benefits. ${ }^{41}$ On the contrary, the social security agreement signed in 2008 between Denmark and the US does not concern transferability of family-related benefits.

Udbetaling Danmark is solely in charge for paying out the family-related benefits, and claimants must contact/apply to the agency directly. As a rule, decisions concerning eligibility are made by Udbetaling Danmark. Consequently, Danish embassies and consulates have no attributes concerning family benefits, but some (like the ones in Sweden, Norway and Germany) provide online information

\footnotetext{
${ }^{37}$ Beskaftigelsesministeriet (2019). LBK nr 63 af 21/01/2019 Bekendtgørelse af lov om børnetilskud og forskudsvis udbetaling afbørnebidrag (online at https://www.retsinformation.dk/Forms/ R0710. aspx?id=205362).

${ }^{38}$ Unless otherwise specified, information in these paragraphs comes from the Danish Agency for Labour Market and Recruitment (Styrelsen for Arbejdsmaked og Rekruttering), https://star.dk/ ydelser-og-ferie/boligstoette-boernetilskud-og-hjaelp-i-saerlige-tilfaelde/boernetilskud/. Accessed 24 August 2018.

${ }^{39}$ Beskaftigelsesministeriet (2019). LBK nr 63 af 21/01/2019 Bekendtg $\phi r e l s e$ af lov om børnetilskud og forskudsvis udbetaling afbørnebidrag (online at https://www.retsinformation.dk/Forms/ R0710.aspx?id=205362). Accessed 24 August 2018.

${ }^{40}$ For further information, refer to the guidance of 31 May 2010 on the EC Regulation on Social Security Coordination Nos. 883-2004, Part IX - Family Benefit Guide.

${ }^{41}$ For details, see BKI nr 12 af 18/08/2014 (online at https://www.retsinformation.dk/forms/R0710. aspx?id=164155). Accessed 24 August 2018.
} 
about these benefits. However, consulates do have some attributes related to families: they register applications for proof (bevis) or preservation (bevarelse) of Danish citizenship (for children born abroad from Danish parents), but they do not issue birth certificates. ${ }^{42}$

\subsubsection{Economic Hardship}

Cash assistance (kontanthjcelp) is the basic support provided to all legal residents in Denmark, provided that certain conditions are fulfilled, including a rule of proven minimum $225 \mathrm{~h}$ of regular work (unsupported by public means, for example via subsidized jobs) in the 12 months prior to the request to receive cash assistance. Details are provided on Borger.dk portal. ${ }^{43}$ Recipients of cash assistance are divided into two categories: "ready to work" (jobparat) or "ready for activation" (aktivitetsparat). They must be in close contact with the job centre responsible for their case, fulfil all the conditions for cash assistance and must be available for work on short-term notice (first category), or participate in preparatory activities for the labour market (the latter category). Therefore, Danish citizens who move abroad with the intention to reside in another country while on cash assistance lose the right to receive it. Danish citizens who reside abroad and fall on tough times cannot claim any cash assistance from the Danish state. Moreover, neither the Nordic Convention, nor the social security agreement signed in 2008 between Denmark and the US provide for possibilities of receiving support from the Danish state in case of economic hardship.

Danish embassies and consulates have no attributes concerning cash benefitsrelated issues. None of the embassies for the five countries included in this overview provides information about accessing this type of benefit, neither in Denmark nor in the host countries.

\subsection{Conclusions}

This chapter found evidence that suggests that the Danish state's engagement with its diaspora is - at least for the time being - limited. Concerning social protection, the study has found that Danish citizens living abroad receive very few social benefits from the Danish state. A main reason for this state of affairs is the fact that most

\footnotetext{
${ }^{42}$ For details, see http://uim.dk/arbejdsomrader/statsborgerskab/danske-statsborgere. Accessed 15 March 2020. An application for the preservation of Danish nationality must reach an Embassy or the Immigration and Integration Ministry at the latest the day before the age of 22 years. If a person makes the request after the age of 22, the person must apply for proof of Danish citizenship.

${ }^{43}$ For details, see https://www.borger.dk/arbejde-dagpenge-ferie/Dagpenge-kontanthjaelp-ogsygedagpenge/Kontanthjaelp/Kontanthjaelp-under-30-med-uddannelse. Accessed 15 March 2020.
} 
of the benefits provided by the Danish welfare state (with the exception of pensions) are conditioned by residence. Moreover, some require additional proofs: for example, proof that a person has worked in Denmark a certain number of years (as in the case of child benefits) or proof that a person is actively looking for work and engaged in improving labour-market skills (as in the case of unemployment benefits). Only in very limited instances the benefits can be transferred abroad. If they find themselves in a situation in which they can transfer some of the welfare benefits across borders, the Danish citizens rely on a well-developed administrative system that allows them to directly contact public authorities online with queries and applications. Therefore, it does not come as a surprise that the Danish embassies and consulates provide very limited services to Danish citizens abroad in the area of social protection. Moreover, as a rule, these institutions do not intervene in favour of Danish citizens experiencing difficulties with their host countries' welfare system.

In addition to the restrictive legal framework, two other factors may explain the limited engagement of the Danish state in diaspora affairs. The first one is the rather negative image that emigrants had in public discourses for most of the last decades. As the sustainability of the Danish welfare state became more of a core topic of contention for policy-makers, the notion that it needs sustained engagement from all members of the society has moved at the forefront of many debates. Contributing by paying the taxes has become thus the criterion according to which individuals' worth in society was judged. In this context, it does not come as a surprise that emigrants were perceived as individuals whom, after benefitting from the welfare state - particularly healthcare and education — do not pay their fair share when it comes to pay taxes (as they choose to pursue a career abroad). In the context of such a negative discourse, it can be argued that Governments were not interested to appear supportive of emigrants with diaspora building policies, or by extending rights to this group.

The second factor has to do with the supra-national institutions and organisations Denmark belongs to. There are several EU regulations that protect the social rights of intra-EU mobile EU citizens (EC Regulation 1408/71 and EC Regulation 883/04). In addition, the Nordic countries have been engaged in a sustained effort to develop and deepen cooperation in the Nordic area. After the Helsinki Treaty (1962) has set the bases of this cooperation, several agreements have been signed with the aim of enhancing the mobility of Nordic citizens among the Nordic countries. These agreements remove the barriers from access to education and labour market, and enhance cooperation between administrations for the calculation and disbursement of social benefits. The existence of these supranational agreements has in all likelihood increased the perception in Denmark that the rights of Danish citizens residing in other countries - in particular in EU and Nordic area - are well protected and secure, and therefore diminish the pressure to create policies specifically targeted at the diaspora.

There are however signs that the Danish Government is interested in developing a new approach towards its diaspora. Accompanying the more positive tone in recent public debates, and the increased awareness about the achievements of Danes 
abroad, the Government has recently launched a few initiatives aimed at strengthening the bonds between the Danish state and Danish diaspora in the future.

Acknowledgements This chapter is part of the project "Migration and Transnational Social Protection in (Post)Crisis Europe (MiTSoPro)" that has received funding from the European Research Council (ERC) under the European Union's Horizon 2020 research and innovation programme (Grant agreement No. 680014). In addition to this chapter, readers can find a series of indicators comparing national social protection and diaspora policies across 40 countries on the following website: http://labos.ulg.ac.be/socialprotection/.

\section{References}

Brogaard Pedersen, K. (2009, March 9). Udvandring ses som forræderi. Metro Express. http:// www.e-pages.dk/metroxpressdk/560/10

CARE. (2010). Consular and diplomatic protection. Legal framework in the EU Member States. Available online at http://www.ittig.cnr.it/Ricerca/ConsularAndDiplomaticProtection.pdf

Copenhagen Goodwill Ambassadors \& Danes Worldwide (CGA\&DW). (2016). The Danish diaspora - An untapped resource? Available online at https://www.danes.dk/fileadmin/user_ upload/The_Danish_Diaspora_an_Untapped_Resource.pdf

Grøngaard Jeppesen, T. (2005). Danske i USA 1850-2000: En demografisk, social og kulturgeografisk undersøgelse af de danske immigranter og deres efterkommere. Odense: Odense Bys Museer i kommission. Syddansk Universitetsforlag.

Madsen, P. H. (2009). Arbejde og kærlighed driver danskere til udlandet. Ugebrevet A4, nr. 30.

Mouritsen, P., \& Hovmark Jensen, C. (2017). Leaving the Fatherland behind - Emigration and diaspora policies in Denmark. In A. Weinar (Ed.), Emigration and diaspora policies in the age of mobility. Cham: Springer.

Redington, N. (2003). Hjerneflugten er afblæst, Ugebrevet A4, nr. 28. http://www.ugebreveta4. dk/2003/28/Tema/Hjerneflugtenerafblaest.aspx

Open Access This chapter is licensed under the terms of the Creative Commons Attribution 4.0 International License (http://creativecommons.org/licenses/by/4.0/), which permits use, sharing, adaptation, distribution and reproduction in any medium or format, as long as you give appropriate credit to the original author(s) and the source, provide a link to the Creative Commons license and indicate if changes were made.

The images or other third party material in this chapter are included in the chapter's Creative Commons license, unless indicated otherwise in a credit line to the material. If material is not included in the chapter's Creative Commons license and your intended use is not permitted by statutory regulation or exceeds the permitted use, you will need to obtain permission directly from the copyright holder.

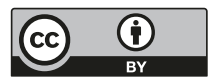

